\title{
The Fiscal History of Boyacá, 1863-1886: Liberal Dreams and Limited Resources
}

\author{
La historia fiscal de Boyacá, 1863-1886: \\ sueños liberales y recursos limitados
}

\begin{abstract}
Joshua Rosenthal
Professor Department of History and Non-Western Cultures of Western

Connecticut State University

rosenthalj@wcsu.edu
\end{abstract}

Fecha de recepción: 30 de septiembre de 2015

Fecha de aceptación: 16 de octubre de 2015

Sugerencia de citación: Rosenthal, J. (2015). The fiscal history of Boyacá, 18631886: Liberal dreams and limited resources. tiempo\&economía, 2(2), 9-32

\section{Resumen}

La historia fiscal de Boyacá entre 1863 y 1886 reflejó la tensión entre la realidad de la economía moribunda del Estado y los ideales progresistas de los liberales radicales que controlaron su gobierno. El Estado se apoyó en tributos utilizados en el pasado colonial, como el de degüello, y en innovaciones liberales, como el impuesto directo, que proveyó una fuente de ingreso sorprendentemente efectiva para una economía subdesarrollada. El patrón de gasto público reflejó la misma tensión dinámica: los costos presupuestados fueron ajustados en línea con los recursos miserables del Estado, que en términos per cápita estaban entre los más bajos de la Confederación. Esta restricción operó cuando se trató de educación, una prioridad del gobierno, pero alcanzó un punto extremo con la fracasada Ferrería de Samacá. Detrás de estos esquemas ambiciosos y de alto costo estaban las promesas de apoyo financiero del Gobierno Federal, aunque no es claro qué tan frecuentemente esas promesas se cumplieron. Esta dinámica fue un factor en la compleja fórmula política en la que Boyacá era un puntal de apoyo del pequeño 
círculo liberal que controlaba el Gobierno Federal, aun cuando sus políticos se quejaban de que Cundinamarca impedía el desarrollo de Boyacá.

Palabras clave: Boyacá, Colombia, historia fiscal.

\title{
Códigos JEL: N26.
}

\begin{abstract}
Between 1863 and 1886 Boyacá fiscal history reflected the inherent tension between the reality of the State's moribund economy and the progressive ideals of the radical Liberals who controlled the government. For revenue the government relied on rents evoking the colonial past, such as the degüello, and liberal innovations, such as the impuesto directo, which proved a surprisingly effective source of income given the undeveloped economy. The pattern of government expenditure also reflected this dynamic tension. Expected costs were generally kept in line with the state's paltry resources, which per capita were among the lowest of the nation. This restraint wavered when it came to education, a priority for the government, and disappeared completely at the prospect of a modern industrial infrastructure. The government sponsored attempts to build better roads or railroads, but reached an extreme with the doomed Ferrería de Samacá. Behind such ambitious and costly schemes were promises of financial support from the Federal Government, though it is not clear how often these promises were kept. This dynamic was a factor in the complex political formula wherein Boyacá was a stalwart supporter of the Liberal clique that controlled the Federal government even as its politicians inveighed against Cundinamarca as a State impeding Boyacense development.
\end{abstract}

Keywords: Boyaca, Colombia, fiscal history.

JEL Codes: N26. 


\section{Introduction}

The history of Boyacá during the Federal period embodies both the longer arcing trends that defined the region's entire nineteenth century and, in a number of ways, the history of the nation. Its reflection of Boyacá's nineteenth century is evident in the desperate attempt to promote economic development, and the gulf between elite political ambitions and social reality. Further, the limited scholarly understanding of Boyacense history between 1863 and 1886 reflects the underdeveloped historiography on politics and economics in Boyacá throughout the nineteenth century. This lacunae renders any investigation of the State during the Federal era useful in that it presents vital information, but it ensures that the tentative conclusions drawn from such investigations circle back to larger, as yet, unanswered questions. Thus an examination of Boyacá's fiscal history provides information on State revenue and politics, and serves to identify important areas for future investigation. In the national panorama, Boyacá's federal history embodied the general tension between visions of economic modernity promoted by the radical Liberals in power and the realities of an economically backward nation. Arguably, there was nowhere in the nation where this tension was as pronounced as in Boyacá; the home of key contributors to the Liberal project of the moment and the region with, perhaps, the least economic potential for development.

In the years that followed Independence Boyacá began to gain a reputation as a place of faded glory. Both contemporary observers and historians compared the splendor of Colonial Tunja and Republican Boyacá, with the later suffering in the comparison. The decline of textile production after Independence is often cited as the catalyst for this decline, though in later dec ades the lack of any agricultural production suitable for export was also noted. ${ }^{1}$ Neither the modest attempts at reform in the second quarter of the century, nor Liberal reforms of mid-century, impacted this state of affairs. At the beginning of the Federal era, the State government faced the same challenges to economic productivity and fiscal stability that had bedeviled its predecessors for half a century. The contrast between the inclinations of the radical Liberals who controlled the State and the economic realities of the Boyacá they sought to transform, was a defining characteristic of this history. ${ }^{2}$ The details of how the progressive elite managed a rural state with a large population is not completely understood, though controlling elections and drawing on support from Liberal networks outside of Boyacá were clearly elements in the system of control. A full examination of how this dynamic shaped Boyacense history requires further archival research and a more complete understanding of the State's internal political dynamics than is currently available, though the general nature of its politics are well known.

1 For works emphasizing that the decline in textile production after Independence see Hermes Tovar Pinzón, "La lenta ruptura con el pasado colonial (1810-1850)," Historia Económica de Colombia, ed. José Antonio Ocampo (Bogotá: Siglo XIX, 1987), 87-118; Luis Corsi Otálora, Boyacá: Atlántida andina (Tunja: Academia Boyacense de Historia, 2005); and Maurice Philip Brungardt, "Tithe Production and Patterns of Economic Change in Central Colombia, 1764-1883" (PhD diss., University of Texas, 1974).

2 Works on the intellectual contributions of Liberals from the State is one of the better developed areas of Boyacense historiography, see Javier Ocampo López, Los hombres y las ideas en Boyacá (Tunja: Publicaciones de UPTC, 1989); and Julio Mondragón Castañeda, Las ideas de paz y de constitucionalidad de los adalides boyacenses en el radicalismo colombiano, 1850-1885: con el texto de la Constitución Política para el Estado de Boyacá (Septiembre 3 de 1869) (Tunja: Publicaciones del Magister en Historia, UPTC, 1991).

tiempo\&economía

Vol. $2 \mathrm{~N}^{\circ} 2$ - Il semestre de 2015 
A few points on both Boyacás internal variation and place within the national political system facilitate the understanding of this history. Though the Province of Tunja dates back to the sixteenth century, its recomposition as the State of Boyacá occurred in 1857 when the provinces of Tunja, Tundama, Casanare, and the cantons of Chinquinquirá and Moniquirá from the antigua provincia of Velez, were merged. InternaIly these provinces were reorganized as Tunja, Tundama, Oriente, and Casanare. After the passage of the Constitution of Rionegro in 1863, another reorganization divided the State into the Departments of Centro, Tundama, Norte, Nordeste, Oriente y Occidente. After 1880 Nordeste was replaced with the Department and Gutierrez, and a few years later the Department of Sugamuxi was created. Tunja remained the political center of the State, but did not wield sufficient power to control the population centers of Sogamoso, Soatá, Santa Rosa, Duitama, or Chinquinquirá. At various moments these centers, which were richer and more economically vital than the capital, defied Tunja's political authority.

Boyacá's place within national politics is more clearly understood. During the Federal era, as was the case for much of its history, the regime in Tunja was a firm ally of the national government in Bogotá. At times coexistence with the national government and its powerful Liberal neighbors of Cundinamarca and Santander weighed heavily on Boyacá, while at others the relationships were viewed favorably by those who felt themselves the rightful rulers of the province. A key result of this political allegiance is that Boyacá single presidential vote would be used to support appropriate Liberal candidates. On occasion Boyacá was transformed into a place of campaigns and battles, but even when wars were fought elsewhere the conflicts affected economic development, the management of revenue, and, as the State provided more than its share of soldiers, the available labor pool. ${ }^{3}$ During the 1850 s there had been artisans' societies in a number of the larger towns, and a few were centers of Melista support during the war that followed April 17, 1854. ${ }^{4}$ How much of this Draconian political support survived into the Federal era; in what form and whether its adherents supported the State government after 1863 is not clear. Further, the role of the State's campesino majority, beyond their fabled allegiance to the Church and their apocryphal status as cannon fodder in civil wars remains a stereotype that has not been sufficiently investigated. ${ }^{5}$

However, it is evident that maintaining Liberal control over the state, and ensuring its vote in national elections, was a priority for the regime, though the degree that this control involved suppressing popular will or apportioning rent seeking between regionally based groups is not clear. A mix of both was probably involved. This system had its costs and its weaknesses. The clearest demonstration of this system, and its costs, took place in 1871 when the government

3 Felipe Pérez argued that the reliance on Boyacense soldiers served as an impediment to their development as citizens as well, Memoria de Gobernador de Boyacá de 1870, 10. The timing of the rebellion suggests that it was in part a response to the education reform of 1870 , but this was not mentioned as a factor in any pronouncement or article. On the reform see Jane Meyer Loy, "Education during the Colombian Federation: The School Reform of 1870," Hispanic American Historical Review, 51:2 (May, 1971), 275-294.

4

5 For an analysis on this point see Dueñas Vargas, Guillermo. "Algunas hipótesis para el estudio de la resistencia campesina en la región central de Colombia, siglo XIX." Anuario Colombiano de Historia Social y de la Cultura 2 (1992): $90-106$. 
of Felipe Pérez, a proponent of progress who sought to limit the role of the Church in public life, was temporarily overthrown by a revolt led by Policarpo Flores. ${ }^{6}$ The revolt began as a local rising in late 1870, and by 1871 Flores had succeeded in taking control over the State government. What prompted the rebellion is not exactly clear. During their brief reign in power, the rebels were careful not to articulate a partisan agenda, stressing that their regime would reflect the will of all Boyacenses though fair and open elections, in contrast to Pérez's government. ${ }^{7}$

Most of the information about the rebellion come from newspapers in Bogotá, where the Liberal establishment observed the rebellion with particular interest. The editors of El Tiempo acknowledged that the complaints over electoral fraud under Pérez were just, but dedicated more attention to how the rebellion would impact Boyacá's vote in the upcoming presidential election. ${ }^{8}$ Various pieces in the Bogotá press expressed concerns over the warlike indigenous population so close to the national capital and the possibility that clergy might whip them into a frenzy. ${ }^{9}$ Though the Federal government was legally prohibited from interfering in State politics, it was clear that a hostile, or even neutral, regime in nearby Tunja was unacceptable. ${ }^{10}$ With support in Cundinamarca Pérez raised an army to retake Boyacá. ${ }^{11}$ By May he had defeated a major rebel force and re-established control over the State shortly thereafter. ${ }^{12}$ After retaking power, Pérez resigned. While his successor Vicente Rueda struck a conciliatory tone, repressive measures followed. In the next presidential elections, Boyacá cast its vote for Manuel Murillo Toro. ${ }^{13}$ The revolt was a minor affair, but it demonstrates the tensions at the heart of the Boyacense political economy. Despite Rueda's conciliatory tone, his restored government published various accounts of a battle in Paipa that detailed, melodramatically, fires set during the conflict. Pronouncements of victory and descriptions of the town as a smoking ruin, were supported by eye witness accounts from Paipa who described an army that included priests

6 On Pérez see Ocampo López, Los hombres y las ideas en Boyacá, 11. For another example of Boyacense radicalism see the Memoria de Gobernador de Boyacá de 1869. For a letter from the jefe politico of the Departmento del Norte describing local priests agitating against the government and handing out ballots during elections see AGN, SR, Ministerio de Interior \#75, F. 842, February 1868. In a less sensational coup, a decade later the State President was temporarily imprisoned by the leader of the fuerza publica Marco Naranjo in April 1883. For notes on this attempted golpe from the Federal government and Santander in support of Aristides Calderón who had returned to power see El Boyacense, May 8, 1883.

7 On reports of conflicts in the region and concern that it would spread, see El Boyacense, December 31, 1870. On the outbreak of the rebellion, see Diario de Cundinamarca, January 1871; Diario de Cundinamarca, January 18, 1871, Ibid, January 25, 1871; and El Tiempo, February 28 \& March 7, 1871. For opinion in Bogotá that was critical of Pérez, but more so of the rebels see El Tiempo, December 5, 1871; and Ibid, May 9, 1871. On the military oligarchy of Boyacá see Ibid, April 18, 1871.

8 Quoted in El Tiempo, March 28, 1871, "Revista" as is the following quote.

9 El Tiempo, April 18, 1871.

10 Several peace commissions from Bogotá failed, Ibid, April 11, 1871; and April 25, 1871. See also Diario de Cundinamarca, April 13, 1871.

11 April 4, and April 18, 1871.

12 See El Tiempo, and Diario de Cundinamarca, April 14, 1871. For a proclamation after the victory, see El Boyacense, May 31, 1871.

13 El Tiempo, August 22, 1871. On forced loans, the role of Boyacá, and peace commissions, see Eduardo Posada-Carbó, "Elections and Civil Wars in Nineteenth-Century Colombia: The 1875 Presidential Campaign," Journal of Latin American Studies, 26:3 (October, 1994), 621-649. 
and indios, invoking the fear that the church would lead an ignorant peasantry in rebellion. Controlling such forces was a necessary prerequisite for allowing the State to reach its potential and far more important than free elections.

While the revolt was a dramatic illustration of the political forces in Boyacá it did not have a measurable impact on the State's economy. In contrast, the War of 1876-7 had a significant impact on the economy and illustrates how the State was affected by national conflicts even though the fighting involved disorder in the western provinces rather than major battles. Reports indicate Boyacá contributed a disproportionate number of combatants to the army, creating a labor shortage. ${ }^{14}$ Further the national government sought to finance the war from its political base with Decree 472 on August 30, 1876 calling for a forced loan to be collected: 400,000 pesos in Cundinamarca; and 200,000 in Tolima, Santander, and Boyacá respectively. ${ }^{15}$ However, the governments of Boyacá, and Santander refused to collect the loan. Simultaneously, insurgents destroyed cadastral surveys further inhibiting the government's ability to collect revenue. ${ }^{16}$ Boyacá low rate of revenue collection following the war testify that the conflict had a significant impact on Boyacá's economy, with returns from the impuesto directo sinking to some of their lowest of the entire era.

\section{Boyacá's economy}

Boyacá's economy was primarily agricultural. Major crops were barley, maíz, potatoes, wheat, and beans. While much of the best agricultural land had been in resguardos controlled by indigenous communities in the Colonial era, resettlement campaigns in the late eighteenth century and repartimiento in the early Republic meant that by 1863 this was no longer the case. In his seminal study Hombre y Tierra en Boyacá, Orlando Fals Borda linked the plague of minifundia to the dispossession and repartimiento. ${ }^{17}$ Though Fals Borda was concerned largely with the twentieth century his observations apply to the nineteenth century as well.

A district survey from 1845 offers an overview on occupation by canton (see Table 1).

14 Park, Rafael Núñez, 168. On Boyacá contributing more soldiers to national military efforts than other states, see María Victoria Dotor Robayo, "Soldados indios: la 'cuota de sangre' del Estado Soberano de Boyacá en el proceso de formación del Ejército Federal y del Ejército de la Unión Colombiana," Revista de Historia Regional y Local, 4:8 (2012), 73-107.

15 Januario Salgar, Memoria de Hacienda y Fomento de 1877, 9-10.

16 Giovanni Fernando Amado-Oliveros, "Estructura administrativa del Estado Soberano de Boyacá (1857-1886)," Estudios Socio-Jurid., 11:1 (Enero-Junio, 2009), 167-8.

17 Orlando Fals Borda, El hombre y la tierra en Boyacá. Bases sociohistóricas para una reforma agraria (Ediciones Documentos Colombianos, 1957). 
Table 1. Occupation by Canton in Boyacá in $1845 .^{18}$

\begin{tabular}{|l|r|r|r|r|}
\hline & Landowners & Laborers & \multicolumn{1}{c|}{ Traders } & \multicolumn{1}{c|}{ Artisans } \\
\hline Centro & 2940 & 6039 & 630 & 1443 \\
\hline Leyva & 1700 & 2310 & 118 & 59 \\
\hline Ramiriquí & 1923 & 6095 & 145 & 163 \\
\hline Cocuy & 1620 & 2065 & 60 & 103 \\
\hline Santa Rosa & 835 & 3130 & 600 & 471 \\
\hline Soatá & 334 & 3430 & 124 & 179 \\
\hline Sogamoso & 4375 & 8085 & 1343 & 1520 \\
\hline Garagoa & 379 & 3668 & 52 & 40 \\
\hline Tensa & 403 & 6345 & 360 & 996 \\
\hline Total & $\mathbf{1 4 , 5 0 9}$ & $\mathbf{4 1 , 1 6 7}$ & 3432 & 4974 \\
\hline
\end{tabular}

The survey demonstrates significant variation from Garagoa and Tensa, where less than ten percent of the surveyed population were landowners, to Leiva where almost forty percent held land. By the survey, two thirds of Boyacá's working male population were laborers, most involved in agriculture. The nature of the conditions under which they were employed, and in what fashion they endured later in the century. A close look at landholding after the sale of old resguardo lands, ideally investigated in tandem with an examination of the cadastral surveys used as a basis for the impuesto directo, discussed below, will provide important information on the dynamics of Republican Boyacá. ${ }^{19}$

The district survey of 1845 also describes widespread animal husbandry, though no particular area seemed to have a robust ranching sector. Low level, small scale textile production was also widespread. There were few areas of concentrated production with the exception of Santa Rosa and Belén, which were listed as producing 50,000 and 20,000 tejas respectively. Though Boyacá had various mineral resources, the survey indicated little active mining. There was a mine owner in Ganchantivá, another in Guayata, and two in Tenza. Only Gachantivá had "miners," listed under occupation, with 20. The addition of Muzo to the state with the incorporation of parts of Vélez in 1857 in theory brought the famous wealth of the emerald mines to Boyacá, but there is no record that this sector contributed to the larger economy. A number of reports refer to interprovincial trade, generally in the border regions with Santander, Cundinamarca, and Casanare. These economic profiles of these areas had more in common with their provincial neighbors, as was demonstrated by Santa Rosa's textile production, which was more in keeping with Santander than the rest of Boyacá. ${ }^{20}$

18 The survey was produced by local officials in response from a questioner sent by the Governor. With a population reported at over 330,000 in 1843 this survey was not exhaustive.

19 To offer one example, the repartimiento de resguardo de Siachoque, a town near Tunja, involved various law suits and land sales by those who received part of the old resguardo continued for several decades. A thorough accounting in the notarial records of the Archivo Regional de Boyacá, where there are legajos of notarial records dedicated to these affairs and other legajos, such as Notario Segundo \#292 documenting a burst of such sales in 1860 , to consult.

20 William McGreevey reports that the cost of shipping cargo between Bogotá and Tunja was one of the cheapest tiempo\&economía

Vol. $2 \mathrm{~N}^{\circ} 2$ - II semestre de 2015 
Despite the economic reforms of mid-century, this profile was more or less in place when the State was created in 1857. One official wrote described the state's fiscal affairs by observing that neither Tundama nor Casanare were capable of covering their expenses, and that properly speaking Tunja didn't have any rents, just large debts. ${ }^{21}$ There is no clear indication that this profile disheartened those seeking economic modernization, nor is there evidence that the majority of Boyacá's population shared the enthusiasm for, or belief in the power of, fiscal reform to transform society. The contrast between the impulse toward economic modernity and the State's poverty, was evident in the profile of revenue streams exploited by Tunja, proposed budgets, and unrealized plans to build infrastructure and foment industry. ${ }^{22}$

One indication of Boyacá's economic stagnation and poverty was its slow rate of population growth, one of the lowest of the nation (see Table 2).

Table 2. Population growth by state, 1851-1898. ${ }^{23}$

\begin{tabular}{|l|c|c|c|}
\hline \multicolumn{1}{|c|}{ Province } & \multicolumn{1}{c|}{1851} & 1898 & Increase \\
\hline Antioquia & 243,388 & 620,000 & $255 \%$ \\
\hline Bolívar & 205,607 & 375,000 & $182 \%$ \\
\hline Boyacá & 379,682 & 685,000 & $180 \%$ \\
\hline Cauca & 323,574 & 800,000 & $247 \%$ \\
\hline Cundinamarca & 317,351 & 630,000 & $199 \%$ \\
\hline Magdalena & 67,764 & 132,000 & $195 \%$ \\
\hline Panamá & 138,108 & & $153 \%$ \\
\hline Santander & 360,148 & 550,000 & $183 \%$ \\
\hline Tolima & 208,108 & 380,000 & $186 \%$ \\
\hline TOTAL & $\mathbf{2 , 2 4 3 , 7 3 0}$ & $\mathbf{4 , 1 8 3 , 0 0 0}$ & \\
\hline
\end{tabular}

Whether the demographic stagnation was caused by civil war, out migration, or existing poverty, it factored into the lack of economic vitality.

\section{Rents \& expenses}

Boyacá's relatively low population growth was matched by its inability to generate significant revenue. Between 1848 and 1872 Boyacá collected, on average, less in pesos than any

per kilometer in Colombia during the nineteenth-century, McGreevey, An Economic History of Colombia 1845$1930,43-5$.

21 AGN, SR, Gobernación de Tequendama, Santander, y Boyacá, leg. 1, fol. 613, October 1857.

22 Salomón Kalmanovitz and Edwin López Rivera, "Las finanzas públicas de la Confederación Granadina y los Estados Unidos de Colombia 1850-1886," Revista de Economía Institucional, 12:23 (segundo semestre/2010), 199228; and Liliana Guatava Alarcón, “Las finanzas públicas del Estado Soberano de Boyacá: 1857-1886." Trabajo de grado para economista, Universidad de Bogotá Jorge Tadeo Lozano, 2011.

23 Alarcón, 92, Anexo L. 
other State except for Magdalena. ${ }^{24}$ But accounting for Boyacá's larger population renders this return shockingly low as its per-capita returns lagged far behind even other poor performing states. For examples, in 1870 Cauca, Tolima, and Santander, collected roughly .40 pesos per resident, while in Boyacá the amount was only .20 pesos per resident (see Table 3). ${ }^{25}$

Table 3. Per capita rents by state $1870 / 71 .^{26}$

\begin{tabular}{|l|r|r|r|}
\hline & Población 1870 & Ingresos 1871 & $\begin{array}{c}\text { Per capita } \\
\text { ingresos in pesos }\end{array}$ \\
\hline Antioquia & 365,974 & 343,546 & .95 \\
\hline Bolívar & 241,704 & 233,250 & .97 \\
\hline Boyacá & 498,541 & 104,600 & .21 \\
\hline Cauca & 435,078 & 212,232 & .48 \\
\hline Cundinamarca & 413,658 & 341,220 & .82 \\
\hline Magdalena & 82,255 & 70,939 & .86 \\
\hline Panamá & 224,032 & 296,349 & 1.32 \\
\hline Santander & 433,178 & 186,889 & .43 \\
\hline Tolima & 230,891 & 117,995 & .51 \\
\hline
\end{tabular}

Though the government seemed to keep anticipated revenue in mind when setting presupuestos for the coming year, it only managed to record surpluses in eight years of this period, while running deficits in seventeen (see Table 4). ${ }^{27}$

Table 4. Annual revenue 1857-1886.28

\begin{tabular}{|l|r|r|r|r|}
\hline Año & \multicolumn{1}{|c|}{ Rentas } & \multicolumn{1}{c|}{ Gastos } & \multicolumn{1}{c|}{ Déficit } & Superávit \\
\hline 1857 & $73.158,0$ & $72.374,4$ & & 783,6 \\
\hline 1858 & $74.485,8$ & $74.635,7$ & 149,9 & \\
\hline 1859 & $50.671,0$ & $84.315,7$ & $33.644,7$ & \\
\hline 1860 & $72.452,0$ & $136.401,5$ & $63.949,5$ & \\
\hline 1862 & $50.671,0$ & $84.315,7$ & $33.644,7$ & \\
\hline 1863 & $81.677,2$ & $94.193,7$ & $12.516,5$ & \\
\hline 1864 & $93.200,0$ & $99.812,6$ & $6.612,6$ & \\
\hline
\end{tabular}

24 Kalmanovitz \& López Rivera, “Las finanzas públicas de la Confederación Granadina,” 213.

25 Boyacá had also been the lowest in per capita revenue collection in 1858 and 1851, Ibid, 212. Alarcón's tables make it clear that these figures were typical for Boyacá during this era. Alarcón, "Las finanzas públicas del Estado Soberano de Boyacá," anexos m \& n.

26 Jorge Orlando Melo, (1987), “Las vicisitudes del modelo liberal, 1850-1988”, en Ocampo José Antonio (compil.) Historia económica de Colombia. Editorial Siglo XXI, Bogotá.

27 Alarcón, “Las finanzas públicas del Estado Soberano de Boyacá: 1857-1886," 9 \& Anexo A.

$28 \mathrm{Ibid}, 80$, Anexo B. 


\begin{tabular}{|l|c|c|c|c|}
\hline 1865 & $120.280,0$ & $120.604,1$ & 324,1 & \\
\hline 1866 & $120.410,0$ & $119.687,8$ & & 722,3 \\
\hline 1867 & $100.415,0$ & $198.158,3$ & $97.743,3$ & \\
\hline 1868 & $100.415,0$ & $179.647,9$ & $79.232,9$ & \\
\hline 1869 & $126.554,9$ & $198.530,8$ & $71.975,9$ & \\
\hline 1870 & $45.690,0$ & $102.978,0$ & $57.288,0$ & \\
\hline 1871 & $96.138,5$ & $70.912,3$ & & $25.226,2$ \\
\hline 1872 & $102.978,0$ & $65.533,0$ & & $37.445,0$ \\
\hline 1873 & $381.041,2$ & & & \\
\hline 1874 & $710.358,4$ & $45.461,9$ & & \\
\hline 1875 & $82.540,1$ & $67.829,1$ & & $14.711,0$ \\
\hline 1876 & $73.772,0$ & $118.384,6$ & $44.612,6$ & \\
\hline 1877 & $181.474,8$ & $266.880,4$ & $85.405,6$ & \\
\hline 1878 & $226.919,2$ & $308.978,0$ & $82.058,9$ & \\
\hline 1879 & $564.898,7$ & $406.504,0$ & & $158.394,7$ \\
\hline 1880 & $582.933,0$ & $579.565,0$ & & $3.368,0$ \\
\hline 1881 & $597.399,0$ & $686.530,6$ & $89.131,6$ & \\
\hline 1882 & $273.751,0$ & $344.435,4$ & $70.684,4$ & \\
\hline 1883 & $278.840,0$ & $391.535,0$ & & \\
\hline 1885 & $302.935,0$ & $426.299,0$ & $123.364,1$ & \\
\hline 1886 & $377.562,8$ & $306.219,7$ & & $71.343,1$ \\
\hline
\end{tabular}

A part from the tendency toward deficits, a review of revenue, expected revenue, costs, and expected costs shows an overall, if sporadic, increase in both revenue and spending (see Table 5).

Table 5. Rentas, gastos, and presupuestos. ${ }^{29}$

\begin{tabular}{|c|c|r|r|r|}
\hline & $\begin{array}{c}\text { Rentas anuales en } \\
\text { Pesos }\end{array}$ & $\begin{array}{c}\text { Gastos anuales en } \\
\text { Pesos }\end{array}$ & $\begin{array}{c}\text { Presupuesto de } \\
\text { rentas en Pesos }\end{array}$ & $\begin{array}{c}\text { Presupuestos de } \\
\text { gastos en Pesos }\end{array}$ \\
\hline 1857 & $73.158,00$ & $72.374,40$ & $107.576,09$ & $79.611,84$ \\
\hline 1858 & $74.489,80$ & $74.635,72$ & $74.229,46$ & $82.928,60$ \\
\hline 1859 & $59.686,09$ & $84.315,72$ & $74.509,80$ & $93.167,72$ \\
\hline 1860 & $72.202,66$ & $136.401,50$ & $72.202,66$ & $72.857,41$ \\
\hline 1862 & $50.671,00$ & $84.315,72$ & $74.509,80$ & $93.167,72$ \\
\hline 1863 & $81.677,20$ & $94.193,65$ & $81.399,50$ & $94.193,65$ \\
\hline 1864 & $93.200,00$ & $99.812,55$ & $81.677,20$ & $103.389,85$ \\
\hline 1865 & $120.280,00$ & $120.604,05$ & $120.860,00$ & $99.819,85$ \\
\hline 1866 & $120.410,00$ & $119.687,75$ & $120.068,86$ & $179.697,85$ \\
\hline 1867 & $100.415,00$ & $198.158,25$ & $100.415,00$ & $179.647,85$ \\
\hline
\end{tabular}

29 Alarcón 80-1, Anexo B. 


\begin{tabular}{|r|r|r|r|r|}
\hline 1868 & $100.415,00$ & $179.647,85$ & $100.415,00$ & $88.300,03$ \\
\hline 1869 & $126.554,90$ & $198.530,82$ & $126.553,88$ & $81.753,00$ \\
\hline 1870 & $45.690,00$ & $102.978,00$ & $125.954,90$ & $70.912,30$ \\
\hline 1871 & $96.138,50$ & $70.912,30$ & $96.138,50$ & $65.533,00$ \\
\hline 1872 & $102.978,00$ & $65.533,00$ & $102.978,00$ & $381.041,23$ \\
\hline 1873 & $341.754,00$ & $381.041,23$ & $341.754,23$ & $45.461,85$ \\
\hline 1875 & $82.540,12$ & $67.829,12$ & $82.540,12$ & $118.384,60$ \\
\hline 1876 & $73.772,01$ & $118.384,60$ & $203.367,30$ & $266.879,75$ \\
\hline 1877 & $181.474,80$ & $266.879,75$ & $181.474,00$ & $406.504,00$ \\
\hline 1878 & $226.919,15$ & $308.978,00$ & $438.818,52$ & $406.504,00$ \\
\hline 1879 & $564.898,65$ & $406.504,00$ & $564.898,65$ & $579.565,00$ \\
\hline 1880 & $582.933,00$ & $579.565,00$ & $582.933,00$ & $686.530,60$ \\
\hline 1881 & $597.399,00$ & $686.530,60$ & $597.399,00$ & $344.435,43$ \\
\hline 1882 & $179.000,00$ & $344.435,43$ & $273.751,00$ & $391.535,00$ \\
\hline 1883 & $278.840,00$ & $391.535,00$ & $278.840,00$ & \\
\hline 1886 & $377.562,75$ & $306.219,65$ & $555.206,02$ & $306.219,65$ \\
\hline
\end{tabular}

One notable point here is that the State had difficulty in covering expenses from its formation in 1857 and was in debt before 1863. Also of note is that within the long term trend of increased revenue and expenses, there were enormous fluctuations year to year. Here the early 1870 s stand out, with returns tripling from 102,978 pesos to 341,754 pesos from 1872 to 1873 , and then falling to $82,540.12$ pesos in 1874. The increase was anticipated, as demonstrated by the $381,041.23$ pesos given for the presupuesto of 1872 and expenses of 1873 , but such ups and downs were not conducive to effective policy or development. The presupuesto for the following year was a modest $45.461,85$. While some of these fluctuations and the general upward trend in revenue collection were products of factors endogenous to Boyacá, contributions from the Federal government were a notable factor in this inconsistency, a topic considered below.

While a survey of the main sources of State revenue, the impuesto directo, el estanco del aguardiente, papel sellado, and degüello does not explain such fluctuations it presents an overview of the most important sources of revenue (see Table 6).

Table 6. Rents in Boyacá, 1857 a $1886 .{ }^{30}$

\begin{tabular}{|c|c|c|c|c|c|c|}
\hline $\begin{array}{c}\text { Renta / } \\
\text { año }\end{array}$ & Aguardientes & $\begin{array}{c}\text { Papel } \\
\text { sellado }\end{array}$ & Degüello & $\begin{array}{c}\text { Impuesto } \\
\text { directo }\end{array}$ & $\begin{array}{c}\text { Instrumentos } \\
\text { públicos }\end{array}$ & $\%$ total \\
\hline 1857 & $46 \%$ & $15 \%$ & & $39 \%$ & & $100 \%$ \\
\hline 1858 & $38 \%$ & $28 \%$ & & $34 \%$ & & $100 \%$ \\
\hline 1859 & $43 \%$ & $22 \%$ & & $22 \%$ & $6 \%$ & $100 \%$ \\
\hline
\end{tabular}

30 Alarcón, "Las finanzas públicas," Anexo E, Tabla XII, 84. An important point here is that Alarcon's data is derived from anual Memorias, though it is not clear how all of these figures were generated or whether they were completely accurate. Regular reporting published in El Boyacense presented a more complex portrait of shortfalls, incomplete returns, and attempts to collect certain rents for years. 


\begin{tabular}{|c|c|c|c|c|c|c|}
\hline 1860 & $37 \%$ & $29 \%$ & & $33 \%$ & & $100 \%$ \\
\hline 1862 & $45 \%$ & $35 \%$ & & $20 \%$ & & $100 \%$ \\
\hline 1863 & $42 \%$ & $18 \%$ & & $39 \%$ & & $100 \%$ \\
\hline 1864 & $42 \%$ & $18 \%$ & & $39 \%$ & & $100 \%$ \\
\hline 1865 & $20 \%$ & $10 \%$ & & $60 \%$ & $10 \%$ & $100 \%$ \\
\hline 1866 & $20 \%$ & $10 \%$ & & $47 \%$ & $7 \%$ & $100 \%$ \\
\hline 1867 & $20 \%$ & $10 \%$ & & $47 \%$ & $7 \%$ & $100 \%$ \\
\hline 1868 & $24 \%$ & $12 \%$ & & $56 \%$ & $8 \%$ & $100 \%$ \\
\hline 1869 & $32 \%$ & $13 \%$ & & $41 \%$ & $10 \%$ & $100 \%$ \\
\hline 1870 & $30 \%$ & $11 \%$ & & $50 \%$ & & $100 \%$ \\
\hline 1871 & $33 \%$ & $12 \%$ & $2 \%$ & $52 \%$ & & $100 \%$ \\
\hline 1872 & $26 \%$ & $12 \%$ & $5 \%$ & $56 \%$ & $2 \%$ & $100 \%$ \\
\hline 1873 & $75 \%$ & & $23 \%$ & $0 \%$ & & $100 \%$ \\
\hline 1874 & $48 \%$ & & $10 \%$ & $40 \%$ & & $100 \%$ \\
\hline 1875 & $86 \%$ & & $14 \%$ & $0 \%$ & & $100 \%$ \\
\hline 1876 & $62 \%$ & $24 \%$ & $9 \%$ & $0 \%$ & $4 \%$ & $100 \%$ \\
\hline 1877 & $50 \%$ & $8 \%$ & $3 \%$ & $36 \%$ & $2 \%$ & $100 \%$ \\
\hline 1878 & $33 \%$ & $13 \%$ & $2 \%$ & $52 \%$ & & $100 \%$ \\
\hline 1879 & $24 \%$ & $10 \%$ & $17 \%$ & $47 \%$ & $1 \%$ & $100 \%$ \\
\hline 1880 & $24 \%$ & $10 \%$ & $17 \%$ & $47 \%$ & $1 \%$ & $100 \%$ \\
\hline 1881 & $23 \%$ & $9 \%$ & $19 \%$ & $46 \%$ & $1 \%$ & $100 \%$ \\
\hline 1882 & $22 \%$ & $11 \%$ & $15 \%$ & $44 \%$ & $2 \%$ & $95 \%$ \\
\hline 1883 & $18 \%$ & $12 \%$ & $12 \%$ & $36 \%$ & $3 \%$ & $82 \%$ \\
\hline 1885 & $20 \%$ & $12 \%$ & $24 \%$ & $38 \%$ & $4 \%$ & $100 \%$ \\
\hline 1886 & $19 \%$ & $12 \%$ & $24 \%$ & $38 \%$ & $4 \%$ & $100 \%$ \\
\hline
\end{tabular}

This list demonstrates the degree the government relied on both traditional and new sources of revenue. The impuesto directo, the single greatest source of revenue in this era, articulated the economic ideals trumpeted by the radicals in power. Though Boyacá's poverty limited what such a tax produced, the success of the impuesto demonstrates the commitment to economic modernization, and the State's surprising capacity to compile annual catastros articulating its institutional presence throughout Boyacá. ${ }^{31}$ In real terms the impuesto directo returned more revenue than any other rent. In assessing the returns for 1873, when the impuesto directo accounted for 40 percent of Boyacá's returns, Kalmanovitz and López Rivera term it a "relativo éxito." ${ }^{\prime \prime 2}$ Though an accurate characterization, the assertion is contingent on comparisons with the states that did not successfully introduce an impuesto directo and, more significantly, the context of fiscal scarcity. Had Boyacás per capita revenues approached those of other States, or if

31 Giovanni Fernando Amado-Oliveros, “Estructura administrativa del Estado Soberano de Boyacá (1857-1886), (artículo de maestría), Estudios Socio-Jurídicos, 11: 1 (enero-junio 2009), 145-179, see 153. In some years it proved impossible to complete a catastro so the Government relied on figures from prior years, as it did in 1877.

32 Kalmanovitz \& López Rivera, “Las finanzas públicas de la Confederación Granadina," 221. 
it had access to other sources of revenue, the impuesto would have been much less important. Another point is that the impuesto tended to fluctuate. Alarcón has suggested that provincial variation in the rate of assessment, noted in 1870, was a way for the State government to reward its allies and punish its opponents. ${ }^{33}$ It is difficult to prove or disprove this assertion, though the varying rate of assessment identified by Alarcón for 1870 did not last. By 1880 the rate was a uniform $4 \%$ as set by law (see Table 7 ).

Table 7. Impuesto directo para 1870 and $1880 .^{34}$

\begin{tabular}{|c|c|c|c|c|c|c|}
\hline & \multicolumn{3}{|c|}{1870} & \multicolumn{3}{c|}{1880} \\
\hline Departamento & Riqueza imponible & Suma a contribuir & $\%$ & Riqueza imponible & Suma a contribuir & $\%$ \\
\hline Tundama & $5.075,770$ & $8,177,55$ & 1.6 & $4.552,755$ & $18,211,15$ & 4 \\
\hline Centro & $3.109,879$ & $8,604,2$ & 2.7 & $4.291,507$ & $17,166,05$ & 4 \\
\hline Oriente & $2.290,531$ & $9,160,92$ & 4 & $2.573,699$ & $10,295,6$ & 4 \\
\hline Occidente & $2.126,992$ & 8,968 & 4.2 & $2.851,284$ & $11,405,15$ & 4 \\
\hline Norte & $1.782,297$ & $8,486,54$ & 4.8 & $1.320,082$ & 5280,35 & 4 \\
\hline Nordeste & 340,836 & 1,197 & 3.5 & 495,404 & 1981,65 & 4 \\
\hline Gutiérrez & - & - & - & $1.058,070$ & 4232,35 & 4 \\
\hline TOTAL & $\mathbf{1 4 , 7 2 6 , 3 0 5}$ & $\mathbf{4 2 , 3 9 4 , 2 2}$ & $\mathbf{2 . 8}$ & $17.142,801$ & $\mathbf{6 8 , 5 7 2 , 3 0}$ & 4 \\
\hline
\end{tabular}

Other problems included the specter of corruption, and shortfalls in collection. While the former is difficult to document, the latter was clearly documented and a constant challenge. The effort to collect direct taxes in 1872 provides an example. After several years of declining returns, and the disorder of 1871 described above, the government in Tunja sought to collect the impuesto of 1871 (here described as "ordinario") an impuesto extraordinario, and an empréstito forzado. In March 1872, El Boyacense reported on collection rates for the three levies: 4019 of 5378 pesos of the impuesto ordinario had been collected; but only 1017 of the 2030 for the impuesto extraordinario, and only 1160 of the 2903 of the empréstito forzoso. ${ }^{35}$

Also illuminating are reports from the 1880s that document inefficiencies in revenue collection, even during a half decade when the impuesto directo provides between $30 \%$ and $50 \%$ of state revenue. An inspection of the office of the Hacienda in the Provincia del Centro in March 1882, and the Provincias del Tundama and Sugamaxi the following month, documented dramatic shortfalls in collection; in the Provincia del Centro only 1480.4 of the expected 24,571.8 pesos had been collected at the time of the inspection (see Table 8). ${ }^{36}$

33 Alarcón, 32.

34 Alarcón, 32, \& El Boyacense, August 14, 1880.

35 El Boyacense, March 6, 1872.

36 Ibid, March 31, 1882.

tiempo\&economía

Vol. $2 \mathrm{~N}^{\circ} 2$ - II semestre de 2015

p. 21 
Table 8. Impuesto expected and collected..$^{37}$

\begin{tabular}{|c|c|c|c|c|c|c|c|c|c|c|}
\hline & 1878 & & 1879 & & 1880 & & 1881 & & 1882 & \\
\hline & Pres. & Coll. & Pres. & Coll. & Pres. & Coll. & Pres. & Coll. & Pres. & Coll. \\
\hline Centro & 1128.375 & 1.60 & 2473.775 & 121.10 & 3330.55 & 36.20 & 4414.70 & 418.075 & 13224.40 & 903.40 \\
\hline $\begin{array}{c}\text { Sugamuxi y } \\
\text { Tundama }\end{array}$ & & & 41.425 & 1.40 & 1145.50 & 12.25 & 372.325 & 14.25 & 1460.80 & 244.90 \\
\hline
\end{tabular}

While such anecdotal reports do not prove that the figures published in the Memorias were based more on presupuestos than reality, they indicate the degree that the fiscal system ran behind collection goals, and are a reminder that the entire system constantly teetering on the point of collapse. Certainly challenges to meeting presupuestos contributed to the trend of returns failing to equal expenses.

Despite such challenges the impuesto's rate of return increased in the 1870s and 1880s (see Table 9).

Table 9. Presupuesto impuesto directo by Province in pesos

\begin{tabular}{|r|r|r|r|r|r|r|r|r|r|}
\hline Province & Tundama & Oriente & Centro & Occidente & Norte & Nordeste & Gutiérrez & Sugamuxi & Total \\
\hline 1864 & 13050 & 8550 & 10050 & 7150 & 9200 & & & & 48000 \\
\hline 1865 & 19575 & 12825 & 15075 & 10725 & 13800 & & & & 72000 \\
\hline 1873 & 13934.2 & 6905.3 & 9864.15 & 8149.13 & 5526.5 & & & & 44379.3 \\
\hline 1874 & 13610.25 & 7056.15 & $10,023.15$ & 8422.05 & 5870 & 1027.4 & & & 46009 \\
\hline 1875 & 13610.3 & 7253.33 & 10095 & 8974.38 & 5945.25 & 1043.6 & & & 46921.8 \\
\hline 1876 & 13666.5 & 7309.65 & 10575.85 & 9745.675 & 6226.525 & 1384.4 & & & 48908.8 \\
\hline 1877 & 13866.5 & 7309.65 & 10575.85 & 9745.675 & $6,226.53$ & 1384.6 & & & $49,108.80$ \\
\hline 1878 & 18487.65 & 9852.6 & 15170.15 & 12993.35 & 8237.7 & 1968.7 & & & 66710.15 \\
\hline 1880 & 18211.2 & 10295.6 & 17166.1 & 11405.2 & 5280.35 & 1981.65 & 4232.35 & & 68572.3 \\
\hline 1881 & 18322 & 10300 & 17392 & 11653 & 5465.3 & 1981.7 & 4314.7 & & 69428 \\
\hline 1882 & 13054.5 & 10163.7 & 14910.3 & 12476.6 & 6080.9 & & 3921.6 & 9282.2 & 69889.8 \\
\hline
\end{tabular}

In part this increase was due to raising the rate of assessment to $4 \%$ of wealth in 1878 . This change was particularly notable in the provinces of Centro and Tundama, the largest and wealthiest in the State. Prior low rates of assessment in these areas may have been the product of political influence, so the reform reflected the implementation of a more regionally equita- 
ble rent. But the increase also stemmed from the rise in assessed wealth across the State, from $14,726,305$ pesos in 1870 to 17,142,801 pesos in 1880 (see Table 6). Reflecting on similar increases across the nation in this era, Kalmanovitz and López cite increased transportation infrastructure and rising rates of education as leading to rising levels of wealth. ${ }^{38}$

In contrast to the innovative impuesto directo, there were the rents directly descended from those of the colonial era. The enduring reliance on traditional revenue sources may have been ill suited to the dominated ideology of the era, but the practice was born of economic necessity. Aguardiente was the most important of these anachronistic rents, supplying between a quarter and half of State revenue depending on the year. The importance of this contribution was enhanced as aguardiente provided revenue in years when the impuesto did not. For example, in five years during the 1870s aguardiente provided 75\% (1873), 48\% (1874), 86\% (1875), 62\% (1876), and 50\% (1877) of the State's total revenue, returning between 24,000 and 38,000 pesos. Anecdotally both the impuesto directo and aguardiente proved easier to manage and collect earlier in the federal era. An 1867 report from Tundama noted that collectors had returned 7037.15 pesos though the presupuesto had stipulated only 6751.2 pesos. ${ }^{39}$ Such excesses were unusual, and Alarcón has documented the increasing gap between expected and actual returns as time passed. ${ }^{40}$

Even more descriptive of Boyacá's retrograde economy was the reintroduction of the degüello tax after 1870. In the decade-and-a-half after this backward looking innovation, the presupuesto for the degüello went through three distinct states: below 10,000 pesos in the 1870s; around 25,000 pesos from 1880-1883; and over 40,000 pesos in 1885 and 1886. The average annual return for these years was 16,145 pesos per year. This high average reflected the relative success of the rent after 1880, when it returned roughly the same amount as aguardiente. Whether this increase was a product of increased institutional efficiency on the part of the Hacienda or represented an increase in Boyacá's role as a transit point for cattle from the Llanos is unclear, though the question remains ripe for investigation. Like the degüello the endurance of colonial style taxes on papel sellado and instrumentos continued to provide small but necessary government funds throughout the Federal era.

One of the most important elements of Boyacá's fiscal history is what was missing, the taxes that the State government could not exploit as they were the province of the Federal government. Aduanas, which by virtue of its proximity to Venezuela, might have had some impact was outside of its control, though not much international trade made its way through Boyacá. More significant, in potential and in practice, was the Federal salt monopoly. Just as the State was unable to break away from colonial revenues, the Federal government maintained monopoly control over the production and sale of salt even through the zenith of Liberal political control.

38 It is also possible that the property controlled by the Church and other institutions had a significant impact on the economy once it was brought into circulation, though as was the case with other indicators Boyacá was a secondary area in this dynamic. See Roberto Luis Jaramillo \& Adolfo Meisel Roca, "Más allá de la retórica de la reacción, análisis económico de la desamortización en Colombia, 1861-1888," Cuadernos de Historia Económica y Empresarial (Cartagena: Banco de la República/Centro de Estudios Económicos Regionales,) \#22 (December 2008). (http://www.banrep.gov.co/sites/default/files/publicaciones/archivos/chee_22.pdf)

39 El Boyacense, May 14, 1867.

40 Alarcón 36.

tiempo\&economía

Vol. $2 \mathrm{~N}^{\circ} 2$ - II semestre de 2015

p. 23

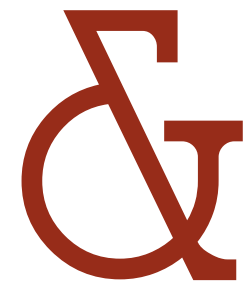


While, the promise and frustrations of the salt monopoly for the national government were a constant throughout the nineteenth century, for Cundinamarca and Boyacá the anachronistic and anti-liberal monopoly deprived them of a share of the most profitable industry in their respective states. ${ }^{41}$ Between 1855 and 1897 the profits from sales in Zipaquirá, Nemocón, Tausa, and Sesquilé in Cundinamarca averaged 660,360 pesos annually; while profits in Chameza and La Salina in Boyacá averaged 60,192, a sum roughly equivalent to returns for the impuesto directo after 1878.

In response to critiques of the monopoly, the Ministerio de Hacienda implemented various reforms in this era. One introduced a system of libre elaboración, which theoretically allowed for market forces to improve the manufacture and sale of salt. ${ }^{42}$ More importantly for Boyacá, in 1869 the Hacienda revised its fiscal code setting aside $1 / 2$ centavo per kilogram sold in government almacenes for a fund to be distributed to those states where the monopoly was still in effect: 35\% for Boyacá, 30\% for Cundinamarca, 22\% for Santander, 10\% for Tolima, and 3\% for Cauca. ${ }^{43}$ This revenue should have provided a substantial contribution to Boyacá, but correspondence makes it clear that the salt administration did not always send the money owed to the State. The presupuesto for 1880 noted that the Hacienda owed the State 70,000 pesos due to previous failures to forward the funds. ${ }^{44}$ By the 1880 s profits from the monopoly were linked directly to the development of a modern industrial infrastructure, and the will to abolish the monopoly had waned even before the Constitution of 1886 and the end of the Federal era.

\section{Costs \& spending}

A review of government expenses and spending describes the same tug of war between liberal ideals and fiscal reality evident in the mixed sources of revenue. The presupuestos de gastos shows that the government attempted to spend no more than it took in. The practical side of this approach was evident in the modest allocations set for each year. The government of Boyacá spent less, in total, than any other state in the nation, except for Tolima and Magdale-

41 See Joshua M. Rosenthal, Salt and the Colombian State. Local Society and Regional Monopoly, 1821-1900 (Pittsburgh: University of Pittsburgh Press, 2012).

42 Ibid, 47-9, 63-71.

43 Boyacá was owed as much as 1500 pesos a month from this fund. For example, in 1875 the fund should have allocated 194,058 pesos as follows: Boyacá 24,935, Cauca 2,137, Cundinamarca 21,373, Santander 15,673, and Tolima; Esguerra, Memoria de Hacienda y Fomento de 1876, 37. For related legislation, see Lei de 15 de abril de 1872 por la cual se ordena el pago de las cantidades que el Tesoro nacional debe a ciertos Estados por la participación que tienen en la renta de Salinas, Aquileo Parra, Memoria de Hacienda y Fomento de 1873, 41. Given the general inefficiency associated with the monopoly and almacenes, it is not clear that all of these funds were delivered. More subtly the networks used to distribute profits from salt works reinforced Liberal political control, as in the 1860s military commanders wrote directly to empleados of the Hacienda in charge of La Salina seeking funds for their military operation. The infrastructure was national but the dynamic underscored the presence of the Liberal government even during an era of high federalism, see Rosenthal, Salt and the Colombian State, 118-119.

44 It was listed as "Deuda de la Nación al Estado por la participación que este tiene en la renta de Salinas, y que se ha dejado de pagar en años anteriores," Ley 34 de 1879, El Boyacense, December 18, 1879. 
na, though neither had a population as large as Boyacá. ${ }^{45}$ Notably the periods of war, whether national wars as in 1860 and 1877, or provincial rebellions as in 1871, did not produce deficits greater than those of other years. This is best understood as indicative of the general inefficiency of revenue collection during war or peace, rather than a testament to the efficiency of the government during war.

While the government was generally circumspect in its expectations and projections for costs and expenses, it failed to exercise such restraint in two crucial areas. The first was education, an area where the government invested considerable funds and energy. This effort included the support of universal primary education and for the state's institutions of higher education; the Colegio de Boyacá and the Instituto Agrícola de Boyacá. Still, Boyacá spent less on education per capita than any other state, and allotted a smaller percentage of its annual presupuesto for education than every state but Magdalena and Panama (see Table 10).

Table 10. Education spending by state. ${ }^{46}$

\begin{tabular}{|l|r|r|r|}
\hline & $\begin{array}{c}\text { Presupuesto } \\
\text { instrucción pública, } \\
\mathbf{1 8 7 1} \text { in pesos }\end{array}$ & $\begin{array}{c}\text { Per capita spending } \\
\text { on instrucción pública } \\
\text { in pesos } \\
\text { (1870 population) }\end{array}$ & $\begin{array}{c}\text { Instrucción } \\
\text { pública as \% } \\
\text { of total presupuesto }\end{array}$ \\
\hline Antioquia & $17.764,00$ & .05 & $5.2 \%$ \\
\hline Bolívar & $48.147,00$ & .20 & $21.2 \%$ \\
\hline Boyacá & $4.496,00$ & .01 & $4.3 \%$ \\
\hline Cauca & $17.390,00$ & .04 & $6.9 \%$ \\
\hline Cundinamarca & $12,200.00$ & .03 & $4.1 \%$ \\
\hline Magdalena & 2000.00 & .02 & $2.9 \%$ \\
\hline Panamá & $10.400,00$ & .05 & $3.0 \%$ \\
\hline Santander & $46.126,00$ & .11 & $21 \%$ \\
\hline Tolima & 9.750 & .04 & $5.6 \%$ \\
\hline Total & 2.928 .311 & .06 & $8 \%$ \\
\hline
\end{tabular}

Despite these comparatively low levels of spending, the government of Boyacá made it clear that promoting education was a priority. El Boyacense was dominated by articles and whole issues reporting on schools and education, and revenue was earmarked to support education. An 1882 report documented this process, with details on how each agencia de Hacienda ensured that money collected from the impuesto directo went directly to instrucción pública (see Table 11).

When the impuesto proved insufficient to cover educational expenses, additional funds were allocated from aguardiente, as was necessary in Tundama, Sugamuxi, and Oriente. Promoting education was a priority for the government, but one that was managed with an eye for the bottom line.

45 Kalmanovitz \& López, “Las finanzas públicas,” 223.

46 Alarcón 91. Anexo K, 92 Anexo L.

tiempo\&economía

Vol. $2 \mathrm{~N}^{\circ} 2$ - II semestre de 2015

p. 25 
Table 11. Impuesto directo and education. ${ }^{47}$

\begin{tabular}{|c|c|c|c|c|c|c|c|}
\hline $\begin{array}{c}\text { Agencias de } \\
\text { Hacienda }\end{array}$ & $\begin{array}{c}\text { Suma de } \\
\text { impuesto que } \\
\text { debe cobrar } \\
\text { cada agente }\end{array}$ & $\begin{array}{l}\text { Sumas que deben } \\
\text { enviarse a la } \\
\text { Admin. Gral. } \\
\text { de Henda. para } \\
\text { gastos de } \\
\text { Instrucción } \\
\text { pública }\end{array}$ & $\begin{array}{l}\text { Cantidad a que } \\
\text { ascienden los } \\
\text { gastos que } \\
\text { deben cubrirse } \\
\text { en cada agencia }\end{array}$ & \begin{tabular}{|c|} 
Sumas que \\
deben dejarse \\
en cada agen- \\
cia para pago \\
de gastos
\end{tabular} & $\begin{array}{c}\text { Remesas que } \\
\text { deben hacerse a } \\
\text { otras agencias }\end{array}$ & \begin{tabular}{|c|} 
Sumas que \\
deben remitir- \\
se a la Admin. \\
Gral. de \\
Hcnda.
\end{tabular} & $\begin{array}{c}\text { Sumas que } \\
\text { deben remi- } \\
\text { tirse por la } \\
\text { Admin. Gral. } \\
\text { de Henda. }\end{array}$ \\
\hline Centro & $13,856.80$ & 3464.20 & 8748.15 & 8748.15 & & 1644.45 & \\
\hline Leiva & 1053.50 & 263.30 & 138 & 138 & & 652.20 & \\
\hline Tundama & 6353.60 & 1588.90 & 8265 & 4764.70 & & & \\
\hline Paipa & 6634.200 & 1658.50 & 900 & 900 & $\begin{array}{l}3499.30 \text { a } \\
\text { Tundama }\end{array}$ & 576.40 & \\
\hline Norte & 6080.90 & 1520 & 7774 & 4560.90 & & & 3213.10 \\
\hline Gutiérrez & 3921.60 & 980.40 & 6003 & 2941.20 & & & 3061.80 \\
\hline Oriente & 7130.30 & 1782.50 & 8346 & 5347.80 & & & 940.10 \\
\hline Garagoa & 3333.40 & 833.30 & 442 & 442 & $\begin{array}{r}2058.10 \text { a } \\
\text { Oriente }\end{array}$ & & \\
\hline Occidente & 5250.30 & 1312.50 & 5636 & 3937.80 & & & 1698.20 \\
\hline $\begin{array}{l}\text { Chiquin- } \\
\text { quirá }\end{array}$ & 7226.30 & 1806.50 & 5723 & 5419.80 & & & 303.20 \\
\hline Sugamuxi & 5245.70 & 1311.40 & 7813.30 & 3934.30 & & & 1635.60 \\
\hline Pesca & 3636.50 & 909.10 & 484 & 484 & $\begin{array}{l}2243.40 \text { a } \\
\text { Sugamuxi }\end{array}$ & & \\
\hline Total & $69,723.10$ & $17,430.60$ & & & 7800.80 & 2873.05 & 10,852 \\
\hline
\end{tabular}

This balance of ambition and caution disappeared when it came to projects embodying the belief that societal transformation was possible via industrial development. One example of this dynamic is in the way Boyacá was swept up in the wider enthusiasm for railroad construction. In the eastern highlands the passion for railroads was manifest largely in the enthusiasm for the Ferrocarril del Norte, a proposed line that would link Cundinamarca and neighboring states to the Magdalena River and ultimately the Caribbean coast. The plan, which included branch lines into Boyacá, had strong support among the radical politicians of the region. ${ }^{48}$ But this project was not even partially completed until the next century, and even then had little contact with Boyacá.

The second example, however, was a purely Boyacense affair, the long standing effort to build a Ferrería in Samacá. In this case the State government, seduced by visions of industrial modernization, directed scarce resources to this ambitious and ultimately unworkable effort. Attempts to build a Ferrería had begun in the 1850 s without much success. The project gained

47 El Boyacense, June 2, 1882.

48 See Salvador Camacho Roldán, "Ferrocarril del Norte," Escritos Varios, volume 3, 31-90. For optimistic assessments of how the Railroad would transform the region, see El Occidente, \#1-9 (July-September 1873); and Memoria de Gobierno de Boyacá de 1874, 26. 
new life after José Eusebio Otálora assumed the State presidency in $1877 .{ }^{49}$ With support from the Federal regime, Tunja threw itself behind the project. Reports extolled the mineral wealth of the valley, proclaiming that the Ferrería would produce enough iron to supply railroad lines across the country, and other elements necessary for creating an industrial infrastructure. Both the Federal and State government poured money into the effort, which was overseen by foreign engineers. The state government established a private company, ceding to it control over the existing buildings, land, and mines, which it had purchased for 12,100 pesos. Further it loaned the company 75,000 pesos to be repaid at an interest rate of $5 \%$ over eight years. Moreover it was the largest investor in the company, purchasing 25 of the 125 offered shares at a cost of 25,000 pesos. ${ }^{50}$ The Federal government contributed 100,000 pesos. ${ }^{51}$

In a metaphor for the vaulting, but ultimately unfulfilled, visions of the era, the effort failed. Engineers determined that the existing buildings would not serve, and the company was dissolved. Tunja then backed an effort to build an entirely new, larger Ferrería. ${ }^{52}$ Reports documenting problems with the construction, particularly the foundation of the central building, and difficulty with the foreign engineers, undermined support for this new effort..$^{53}$ In the Memoria de Hacienda de 1881, Felipe Paúl lay part of the blame for the slow progress on the ambitious size of the project, and singled out Otálora for particular censure. ${ }^{54}$ In the Memoria de Hacienda of 1882, Salvador Camacho Roldán argued that Ferrería should be abandoned, and a Congressional commission submitted a report advising the same the following year. ${ }^{55}$ Otálora's surprising ascension to the national presidency in 1882, after the death of Francisco Javier Zaldúa, temporarily prolonged efforts to salvage the doomed project. ${ }^{56}$ But even the support of the President of the nation could not save Ferrería. An 1884 report estimated that resuscitating the Ferrería would cost 50,000 pesos and it was abandoned later that year. ${ }^{57}$

49 Nepomuceno Rodríguez, Informe relativo a la ferrería de Samacá (Bogotá: Imprenta de Medardo Rívas, 1883 ), 5.

50 “Informe sobre la visita practicada por la comisión de la asamblea legislativa en la Ferrería de Samacá," Documents relativos á la Ferrería de Samacá (Tunja: Imprenta de Torres Hermanos y compañía, 1879), 6; and “Contrato celebrado ente el doctor Antonio Roldan y el Señor Carlos Otto Brown," Ibid, 13. Informe de la comisión nombrada para practicar una visita en la Ferrería de Samacá (Bogotá: Imprenta a cargo de H. Andrade, 1880), 5. On Federal funding, see ley 36 de 1880, Memoria de Fomento de 1884, 91-92.

51 For claims the Ferrería would produce enough iron for railroads and bridges, see El Boyacense, February 11, 1879. On the Federal Government providing 100,000 pesos in 1879, see Salvador Camacho Roldán, Memoria de Hacienda de 1881, 32. See pictures in Pinto Escobar, Progreso, industrialización y utopía, 37; and descriptions in El Boyacense, January 28, 1881.

52 Pinto Escobar, Progreso, industrialización y utopía, 31.

53 El Boyacense, September 28, 1881; November 5, 1881; and December 10, 1881. A particularly damning report from Thomas Nichols was published in El Diario de Cundinamarca, Pinto Escobar, Progreso, industrialización y utopía, 36-38.

54 Felipe Paúl, Memoria de Hacienda de 1881, 32.

55 Roldán, Memoria de Hacienda de 1882, 45-48; and Park, Rafael Núñez, 252-253.

56 Pinto Escobar, Progreso, industrialización y utopía, 38-40. Law 46 of 1882 set aside 5\% of salt returns from Cundinamarca to support the Ferrería, as well as another $5 \%$ for the Ferrocarril de Soto in Santander, El Boyacense, March 10, 1883.

57 Último informe relativo a la Ferrería de Samacá (Bogotá: Medardo Rivas, 1884).

tiempo\&economía

Vol. $2 \mathrm{~N}^{\circ} 2$ - Il semestre de 2015

p. 27 
By 1887 the Government of Boyacá, forced to cover its debts by Federal law 40 of 1884, sought to recoup its investments by using the buildings as a textile factory. ${ }^{58}$ In 1889 the Fábrica de Hilados y Tejidos of Samacá opened, a humbler example of industrial modernization than that envisioned during the Federal era. There are multiple ironies in this history. The first is that plans to resuscitate Boyacá's declining textile industry with modern techniques had been forwarded since the earliest days of the Republic, but it was not until the overwhelming failure in Samacá that they were realized..$^{59}$ The second, is that the opening of the Fábrica coincided with the Regeneration, when the excesses of the Federal era were abandoned or undone. The Fererría serves as a metaphor for the failed ambitions of the Federal Republic. At a minimum, the State of Boyacá and the Federal Government both invested 100,000 pesos, though various estimates put the figure much higher. Considering that the reported gastos for Boyacá in 1877 totaled 266,880 pesos, these were considerable quantities. That the government was willing to bear such costs demonstrates the depth of the support for economic development via modernization in Boyacá.

This episode also demonstrates the degree that Boyacá was connected to and dependent upon the Federal regime. As noted above, some of the fluctuations in the State's expected revenue involved Federal contributions. Many of the projects involving modernization or intended to foster the development of infrastructure were dependent on Federal funds. A notice in El Boyacense in late 1879 announced that the "Union" owed Boyacá \$357,500 pesos, "procedente de deudas contraidas por aquél y de auxilios decretados por el Congreso".60 Moreover, after the New Year the state expected a further 130,000 pesos from the national government. ${ }^{61}$ With these, "créditos del Estado contra la Nacion," and the 24,000 owed to the State by the Compañía del Ferrocarril del Carare, the Hacienda would enter expected revenue as the "extraordinarias," 511,500 pesos. Such funds were no easier to collect, nor more dependable than the impuesto directo. The facile assertion that these figures should be included in presupuestos de gastos for the following year were as illusory as the contemporary plans for a Ferrería that would produce enough steel to launch Colombian into modernity.

58 El Boyacense, October 26, 1877. On starting a textile company, see AGN, SR, Gobernación de Boyacá \#1, F. 107, 208, January 1888. This effort took another decade and its modest success was overshadowed by the earlier failure, "After the disasters suffered by the various businesses in the iron works of Samacá, destroying almost completely the hopes that existed for its construction and the production, and when the valuable resources in that place are threatened with complete ruin, the idea to dedicate that establishment to another type of industry has been accepted," Memoria de Gobierno de Boyacá de 1896, 58.

59 See such a proposal in a report from the intendente de Boyacá in 1830 Bernardino Soban that anticipated many of the schemes from later in the century. AGN, SR, Ministerio de Hacienda, legajo 254, ff. 445-46, July 1830.

60 The amount was broken down as follows, "Deuda de la Nación al Estado por la participación de éste en la renta de Salinas, 60,000 pesos; auxilio para la Carretera del Sur 25,000 pesos; auxilio para la construcción del Puente de Soto 10,000 pesos; auxilio para la construcción del monumento en el Puente de Boyacá 26,000 pesos; auxilio para la mejora del Camino de Chontáles 10,000 pesos; auxilio para el fomento de empresas materiales, con destino especial al Ferrocarril 200,000; suma adeudada del auxilio para la Carretera del Sur 24,500; auxilio para el Puente de Súnuba 2000, El Boyacense, December 2, 1879.

61 For the following: auxilio para la Ferrería 100,000 pesos; auxilio para gastos de viaje de familias de obreros 20,000 pesos; lo causado á deber por la Nación por el derecho de Salinas, desde $1 .^{\circ}$ de Enero hasta 10 de Julio ultimo (aproximación) 10,000 pesos, Ibid. 
But they also suggest that the radicals of Boyacá were confident that the Federal government would repay the State's political loyalty in very clear terms. It also explains how such a poor state could attempt so many costly projects.

Not all of these projects were as outlandish as the Ferrería. As demonstrated by the list above, much of the effort was directed toward improving Boyacás infrastructure through humbler projects. El Boyacense carried frequent references to contracts and plans for improving roads. The most important of these were the Camino de Occidente and the Camino del Sur, though even these practical projects tended to excite unrealistic schemes. In 1879 the government sought to create a company that would build a short railroad along the route of the Camino del Sur, from Tunja to Ventaquemada. ${ }^{62}$ In general, the Camino de Occidente, which would provide access to Moniquirá and Chinquinquirá, was a higher priority. ${ }^{63}$ This route not only promised access to the Magdalena, but bypassed Cundinamarca. While tensions with Cundinamarca and Santander were normally kept in check, at times the frustration with the former was evident, as when Felipe Pérez wrote:

Creo pues honorables diputados, llegado el momento de poner mano a la grande obra de la regeneración industrial del Estado: el camino de Occidente. Esa empresa había sido hasta ahora un sueño, porque para abrirlo teníamos que contar con la voluntad extraña de Cundinamarca; ... Ibamos pues a agotar nuestros recursos para una empresa nuestra al parecer, pero sujeta en un todo a los caprichos y a la legislación de otro soberano. ${ }^{64}$

A decade later, José Otálora informed the public about the dispute with the junta de caminos of Cundinamarca, which insisted on illegally taxing goods in transit, via Honda for Boyacá:

Cundinamarca puede perder un poco del polvo de sus caminos, que traen acaso en los cascos las bestias conductoras de efectos fabricados en los Estados Unidos ó en Europea; pero en cambio recibe los ganados de Casanare, el batán, el azúcar, el tabaco y el cacao de Santander, que pasan por territorio boyacense sin sufrir, en equitativa compensación de servicios, el gravamen odioso de las contribuciones de tránsito ó de peajes. ${ }^{65}$

62 Boletin de la Esposicion Nacional de Boyacá, June 2, 1879. (http://www.bibliotecanacional.gov.co/recursos_ user/hemerografico/ps19_boletinesposicion_junio_1879.pdf).

63 See La Asamblea Legislativa del Estado Soberano de Boyacá, Decreto de 14 de Noviembre de 1867 que promueve la apertura del camino de Occidente, in Terriorio Vásquez. Documentos sobre límites de los extinguidos Estados de Boyacá y Cundinamarca, Administración del Territorio, Camino de Occidente y Tierras baldías (Tunja: Imprenta del Departamento, 1912), 98-100.

64 Felipe Pérez, Informe del presidente F. Pérez, en 1870. Ensanche territorial y puerto sobre el rio Magdalena, Ibid, 106. References to tension over the political dominance of Cundinamarca, which would prove so important in restoring Pérez's rule in 1871, were sporadic but consistent. A letter to President Salgar in 1871 from Enrique Cortés describes a night spent with a party of armed insurgents who gave them a pamphlet decrying the influence of Cundinamarca over Boyacá, Archivo General de la Nación, Sección República, Ministerio de Gobierno \#81, F. 487-489, September 1871.

65 See two pieces decrying this situation, El Boyacense, April 9, 1881, and June 8, 1881.

tiempo\&economía

Vol. $2 \mathrm{~N}^{\circ} 2$ - II semestre de 2015

p. 29

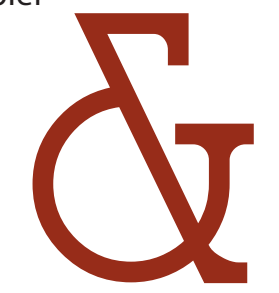


While the government of Santander did not levy taxes on imports passing through the state, the route, via Lebrija and, presumably, the Sogamoso River, was too slow. Several thousand crates of goods necessary for industry, including the Fererría de Samacá, and educational material were delayed in Cundinamarca by these machinations. A call for construction proposals for the Camino de Occidente noted that it would connect their rich highlands to the Magdalena, "pasando por territorio propio, redimiera de una vez y para siempre a Boyacá de tan oneroso tributo." ${ }^{\prime 66}$

The theme of Boyacense autonomy informed other projects intended to foster economic modernization. In 1874 the government investigated the possibility of establishing a state Bank. In presenting the relative benefits of a commercial bank against one that would write mortgages, the author pointed out that both Cundinamarca and Santander had such institutions and argued that interest rates were high in Boyacá as a result, "Ya que empezamos a cultivar la intelijencia, por medio de las escuelas; ya que empezamos a facilitar la movilización de las personas i el trasporte de las cosas, por medio de las vías de comunicación; empecemos a facilitar el ejercicio de la industria, buscando los medios de conseguir los capitales que se necesitan." ${ }^{67}$ As with many projects of the era, this did not prove an immediate success.

\section{Conclusion}

The review of Boyacá's fiscal history provides little to surprise those familiar with its history. Information on revenue and spending confirms what is normally assumed about the State's stagnant economy, its particular place within the national political system, and the attempt by Liberal politicians to remake the region. The degree that Boyacá sought to trade its political loyalty for direct financial support from the Federal regime is striking. This is not an assertion that Boyacense Liberals were not sincere supporting the Federal regime, merely an observation that the relationship between those in control of the state and the Federal government was complex and went beyond formal politics. The rulers of Boyacá expected the Federal government to provide material support for their schemes to transform society and they received assurances that this support would be provided, though Boyacá did not always make good on these promises. Further, the relationship with the Federal regime did not preclude tension with the state of Cundinamarca.

Perhaps the most useful point of this survey is to highlight specific questions that need to be addressed in the relatively underdeveloped historiography of Boyacá: the workings of pop-

66 El Boyacense, September 1, 1881. For a call for bids the following year, see Ibid, January 12, 1882. See, for example, the notice on Law 21, 1882, passed on November 29, permitting the State President to concede privileges to those seeking to open, "nuevas vías de comunicación, construir puentes, ...," Ibid, December 9, 1882.

67 The author claimed the result was Boyacenses paid between 18 and 24\% interest on loans rather than the 12 to $15 \%$ that was the norm in the neighboring States. J. del C. Rodríguez claimed, "Comisión de revisión del proyecto de lei "sobre establecimiento de Bancos," El Boyacense, October 17, 1874. This effort continued in the 1880s. See a notice from June 1881 from Manuel María Fajardo and Ricardo Vargas V., calling for a sociedad anónima to back the bank, El Boyacense, June 4, 1881, and June 9, 1881. A following notice advised the group sought to sell 200 shares to raise 40,000 pesos, claiming the State government had purchased twenty shares, Otálora had purchased five; and other notables were participating, so that 25,000 pesos had already been raised, Ibid, July 14, 1881. 
ular politics and the interplay with a more precise understanding of the mechanisms of Liberal political control, the nature of provincial variation in the state, and the economic history of the state during the Regeneration. These questions aside the review of Boyacás fiscal history also documents how closely Boyacense history matched the contours of the national history, with the exception that the state had no incipient economic sector on the point of achieving success. Even what became one of its most important economic successes, the Fábrica de Tejidos, was founded after the passage of the Constitution of 1886, an apt metaphor for the frustrated ambitions of the era.

\section{References}

Alarcón, L. G. (2011). Las finanzas públicas del Estado Soberano de Boyacá: 1857-1886. Trabajo de grado para Economista, Universidad de Bogotá Jorge Tadeo Lozano.

Amado-Oliveros, G. F. (2009). Estructura administrativa del Estado Soberano de Boyacá (18571886) (artículo de maestría), Estudios Socio-Jurídicos, 11: 1 (enero-junio), 145-179.

Boletin de la Esposicion Nacional de Boyacá, June 2, 1879. (http://www.bibliotecanacional.gov. co/recursos_user/hemerografico/ps19_boletinesposicion_junio_1879.pdf).

Brungardt, M. P. (1974). Tithe production and patterns of economic change in central Colombia, 1764-1883 (PhD diss., University of Texas).

Camacho Roldán, S. (1892). “Ferrocarril del Norte,". In Escritos Varios, volume 3. Bogotá: Librería Colombiana.

Corsi Otálora, L. (2005). Boyacá: Atlántida andina. Tunja: Academia Boyacense de Historia.

Documentos relativos á la Ferrería de Samacá. (1879). Tunja: Imprenta de Torres Hermanos y Compañía.

Dueñas Vargas, G. (1992). Algunas hipótesis para el estudio de la resistencia campesina en la región central de Colombia, siglo XIX. Anuario Colombiano de Historia Social y de la Cultura 2: 90-106.

Fals Borda, O. (1957). El hombre y la tierra en Boyacá. Bases sociohistóricas para una reforma agraria. Bogotá: Ediciones Documentos Colombianos.

Informe de la comisión nombrada para practicar una visita en la Ferrería de Samacá. (1880). Bogotá: Imprenta a cargo de H. Andrade.

Jaramillo, R. L. \& Meisel Roca, A. (2008). Más allá de la retórica de la reacción, análisis económico de la desamortización en Colombia, 1861-1888. Cuadernos de Historia Económica y Empresarial. Cartagena: Banco de la República/Centro de Estudios Económicos Regionales, \#22 (December). (http://www.banrep.gov.co/sites/default/files/publicaciones/archivos/ chee_22.pdf)

Kalmanovitz, S. and López Rivera, E. (2010). Las finanzas públicas de la Confederación Granadina y los Estados Unidos de Colombia 1850-1886. Revista de Economía Institucional, 12 (23): 199-228.

McGreevey, W. (1971). An Economic History of Colombia 1845-1930. Cambridge University Press. 
Melo, J. O. (1987). Las vicisitudes del modelo liberal, 1850-1988. In J. A. Ocampo (compil.), Historia económica de Colombia. Bogotá: Editorial Siglo XXI.

Meyer Loy, J. (1971). Education during the Colombian Federation: The School Reform of 1870. Hispanic American Historical Review, 51 (2): 275-294.

Mondragón Castañeda, J. (1991). Las ideas de paz y de constitucionalidad de los adalides boyacenses en el radicalismo colombiano, 1850-1885: con el texto de la Constitución Política para el Estado de Boyacá (Septiembre 3 de 1869). Tunja: Publicaciones del Magister en Historia, UPTC.

Ocampo López, J. (1989). Los hombres y las ideas en Boyacá. Tunja: Publicaciones de UPTC.

Park, J. W. (1985). Rafael Núñez and the politics of Colombian regionalism, 1863-1886. Baton Rouge \& London: Louisiana State University Press.

Pinto Escobar, I. (1997). Progreso, industrialización y utopía en Boyacá: el caso de la siderúrgica de Samacá. Tunja: Publicaciones del Magister en Historia, Universidad Pedagógica y Tecnológica de Colombia.

Posada-Carbó, E. (1994). Elections and civil wars in nineteenth-century Colombia: The 1875 presidential campaign. Journal of Latin American Studies, 26 (3): 621-649.

Rodríguez, N. (1883). Informe relativo a la ferrería de Samacá. Bogotá: Imprenta de Medardo Rivas.

Rosenthal, J. M. (2012). Salt and the Colombian state. Local society and regional monopoly, 18211900. Pittsburgh: University of Pittsburgh Press.

Robayo, M. V. (2012). Soldados indios: la 'cuota de sangre' del Estado Soberano de Boyacá en el proceso de formación del Ejército Federal y del Ejército de la Unión Colombiana. Revista de Historia Regional y Local, 4 (8): 73-107.

Territorio Vásquez. Documentos sobre límites de los extinguidos Estados de Boyacá y Cundinamarca, Administración del Territorio, Camino de Occidente y Tierras baldías. (1912). Tunja: Imprenta del Departamento.

Tovar Pinzón, H. (1987). La lenta ruptura con el pasado colonial (1810-1850). Historia económica de Colombia, ed. José Antonio Ocampo (pp. 87-118). Bogotá: Siglo XIX.

Último informe relativo a la Ferrería de Samacá. (1884). Bogotá: Medardo Rivas. 